\title{
Analisis Diskriminan sebagai Alat Manajemen Risiko Pembiayaan pada Lembaga Keuangan Mikro Syariah, KBMT Wihdatul Ummah
}

\author{
Sheila Santika Putri \\ Departemen Manajemen, Fakultas Ekonomi dan Manajemen \\ Institut Pertanian Bogor \\ Kampus Darmaga Bogor 16680 \\ Abdul Kohar Irwanto \\ Departemen Manajemen, Fakultas Ekonomi dan Manajemen \\ Institut Pertanian Bogor \\ Kampus Darmaga Bogor 16680 \\ R. Dikky Indrawan \\ Departemen Manajemen, Fakultas Ekonomi dan Manajemen \\ Institut Pertanian Bogor \\ Kampus Darmaga Bogor 16680 \\ e-mail : rdikky@gmail.com
}

\begin{abstract}
Anlslamic microfinanceinstitution, one of whose activitiesisto conduct financing, can not be separatedfromfinancing risks, which can be assessedbythe ratio ofNon Performing Financing (NPF). Thetrendof NPFatKoperasi Baitul Maal wa Tamwil (BMT)-Wihdatul Ummah tended to decrease, but it is forecasted to improveinthe next 3 years. Inorder toassessthe feasibility ofthe debtorupon manageable financing risksan evaluation is required. Furthermore, an evaluationupon feasibility ofthe debtorin obtainingfactors affecting assessment system on financing risk level can be carried out by usingdiscriminantanalysis. These factorsareestimate of character and requirement ofBMT.

Keywords: islamic microfinance institutions, financing, financing risk, discriminant analysis
\end{abstract}

\begin{abstract}
ABSTRAK
Sebagai lembaga keuangan mikro syariah, yang kegiatannya melakukan pembiayaan, tidak dapat dipisahkan dari pembiayaan risiko. Risiko pembiayaan dinilai oleh rasio Non Performing Financing (NPF). Trend NPF di Koperasi Baitul Maal wa Tamwil (BMT)-Wihdatul Ummah cenderung menurun, namun menunjukkan perbaikan dalam peramalan 3 tahun berikutnya. Diperlukan evaluasi dalam menilai kelayakan debitur untuk risiko pembiayaan yang dapat dikendalikan. Mengevaluasi kelayakan debitur memperoleh faktor-faktor yang mempengaruhi sistem penilaian tingkat risiko pembiayaan melalui analisis diskriminan. Faktor-faktor ini adalah pendekatan variabel karakter dan persyaratan dari BMT. Keywords: lembaga keuangan mikro syariah, pembiayaan, risiko pembiayaan, analisis diskriminan
\end{abstract}

\section{Pendahuluan}

Lembaga keuangan mikro (LKM) adalah lembaga yang melayani keuangan mikro (Abdullah 2004). Lembaga keuangan syariah adalah lembaga keuangan yang usaha pokoknya memberikan kredit dan jasa-jasa lain dalam lalu lintas pembayaran serta 
peredaran uang yang beroperasi disesuaikan dengan prinsip-prinsip syariah (Sudarsono 2008). Menurut Muhammad (2005), pembiayaan atau financing yaitu pendanaan yang diberikan oleh suatu pihak kepada pihak lain untuk mendukung investasi yang telah direncanakan, baik dilakukan sendiri maupun oleh lembaga. Dengan kata lain, pembiayaan adalah pendanaan yang dilakukan untuk mendukung investasi yang telah direncanakan.

Salah satu lembaga keuangan adalah Baitul Maal wa Tamwil (BMT), yang pada dasarnya terdiri dari dua istilah, yaitu baitul maal dan baitut tamwil. Baitul maal lebih mengarah pada usaha-usaha pengumpulan dan penyaluran dana yang non-profit, seperti zakat, infaq, dan shodaqoh. Sedangkan baitut tamwil sebagai usaha pengumpulan dan penyaluran dana komersial. Usaha-usaha tersebut menjadi bagian yang tidak terpisahkan dari BMT sebagai lembaga pendukung kegiatan ekonomi masyarakat kecil dengan berlandaskan syariah. Peran umum BMT yang dilakukan adalah melakukan pembinaan dan pendanaan yang berdasarkan sistem syariah (Sudarsono 2008).

Setiap lembaga keuangan yang melakukan pembiayaan tentunya tidak terlepas dari risiko pembiayaan. Pembiayaan untuk usaha mikro kecil dan menengah (UMKM) memiliki jaminan aset yang tidak terlalu besar, untuk itu kemungkinan risiko pembiayaan dinilai cukup besar. Agar risiko tidak merugikan, BMT harus bisa melakukan sistem manajemen risiko pembiayaan yang baik untuk meminimalkan risiko. Sistem manajemen risiko yang dapat dilakukan adalah dengan memperhatikan faktor-faktor yang mempengaruhi karakteristik kinerja nasabah penerima pembiayaan. Menurut Sofyan (2005), manajemen risiko dapat diartikan sebagai usaha seorang manajer untuk mengatasi kerugian secara rasional agar tujuan yang diinginkan dapat tercapai secara efektif dan efesien. Menurut Kasidi (2010), manajemen risiko adalah usaha yang secara rasional ditujukan untuk mengurangi kemungkinan terjadinya kerugian.

Produk pembiayaan BMT menurut Sudarsono (2008) berupa penyediaan uang dan tagihan berdasarkan persetujuan/kesepakatan pinjam-meminjam di antara BMT dengan pihak lain yang mewajibkan pihak peminjam untuk melunasi utangnya beserta bagi hasil setelah jangka waktu tertentu. Koperasi BMT Wihdatul Ummah yang berlokasi di Gunung Batu, Bogor juga menghadapi risiko pembiayaan. Dalam lima tahun terakhir trend risiko yang dihadapi meningkat seiring dengan peningkatan nilai Non Performing Financing (NPF) yang dihadapinya. Oleh karena itu, perlu dikaji sistem manajemen risiko pembiayaan suatu lembaga keuangan mikro syariah, khususnya dalam menyusun kelas kelayakan koletabilitas sebagai dasar penilaian kelayakan pembiayaan.

Hayati (2006) dalam penelitiannya terkait dengan Identifikasi Risiko Operasional Bidang Pembiayaan pada Lembaga Keuangan Mikro di KBMT Wihdatul Umah lebih menfokuskan kepada risiko operasional, masihdiperlukan pendalaman pada sistem penilaian pembiayaan, khususnya pada karakteristik nasabahnya. Penelitian terkait hal ini antara lain dilakukan oleh Bhakti (2009) yang mengemukakan bahwa analisis sistem kelayakan kredit mempertimbangkan 23 variabel penilaian terhadap debitur sebagai parameter pemberian kredit. Dari hasil analisis diskriminan muncul lima fungsi pembeda yang akan mengklasifikasikan kelas kolektibilitas. 
Penelitian ini bertujuan untuk : 1) menganalisis faktor-fakor yang paling mempengaruhi dari sistem penilaian kelayakan mitra di dalam menentukan kolektibilitas mitra sesuai dengan fungsi diskriminan, dan 2) menganalisis faktor-fakor yang paling mempengaruhi dari sistem penilaian kelayakan mitra di dalam menentukan periode pembiayaan mitra sesuai dengan fungsi diskriminan.

\section{Metode Penelitian}

Non Performing Financing (NPF) adalah pembiayaan bermasalah yang terdiri dari pembiayaan yang berklasifikasi kurang lancar, diragukan dan macet. Terminologi Non Performing Loan (NPL) diperuntukkan bagi sistem konvensional, sedangkan NPF untuk sistem syariah. Sebagai lembaga keuangan syariah yang membiayai usaha mikro dinilai risikonya sangat tinggi. Tingginya risiko pembiayaan syariah mengindikasikan adanya pembiayaan bermasalah yang dinyatakan dengan rasio NPF, dimana semakin tinggi rasio NPF maka semakin besar potensi bermasalah dari pembiayaan yang telah diberikan.

Usaha-usaha mikro yang dibiayai oleh KBMT Wihdatul Ummah dinilai banyak yang tidak memenuhi syarat perbankan atau disebut unbankable, sehingga terdapat perbedaan penilaian kelayakan mitra yang diterapkan di KBMT Wihdatul Ummah. Untuk itu perlu dievaluasi faktor-faktor apa yang menjadi pertimbangan dalam penilaian kelayakan mitra. Faktor-faktor tersebut akan mempengaruhi KBMT Wihdatul Ummah dalam menentukan kolektibilitas dan periode pembiayaan yang tepat bagi mitra. Ketepatan dalam menempatkan mitra ini akan berpengaruh terhadap risiko pembiayaan.

Faktor-faktor tersebut dievaluasi dari Memorandum Analisis Pembiayaan (MAP) sebagai dasar penilaian kelayakan mitra yang digunakan oleh KBMT Wihdatul Ummah. MAP tersebut berisi penilaian dengan pendekatan 5C (character, capacity, collateral, condition, dan capital) dan persyaratan BMT. Melalui MAP ini akan dikelompokkan variabel-variabel apa saja yang berpengaruh besar terhadap peningkatan risiko pembiayaan. Pengelompokkan variabel-variabel ini menggunakan analisis diskriminan dan kerangka pemikiran penelitian ini seperti terlihat pada Gambar 1.

Penelitian ini dilaksanakan di KBMT Wihdatul Ummah yang berlokasi di jalan Mayjen Ishak Djuarsa No. 226 G Gunung Batu, Bogor. Pemilihan lokasi dilakukan secara sengaja (purposive) karena KBMT Wihdatul Ummah ini memiliki aktivitas pembiayaan syariah dengan berbadan hukum koperasi syariah. Penelitian ini dilakukan pada bulan Februari-Maret 2012.

Dalam penelitian di KBMT Wihdatul Ummah ini digunakan data sekunder sebagai acuan awal. Data sekunder berupa laporan keuangan NPF KBMT Wihdatul Ummah pada tahun 2006-2011 dan data MAP mitra yang telah diisi oleh Account Officer (AO). 


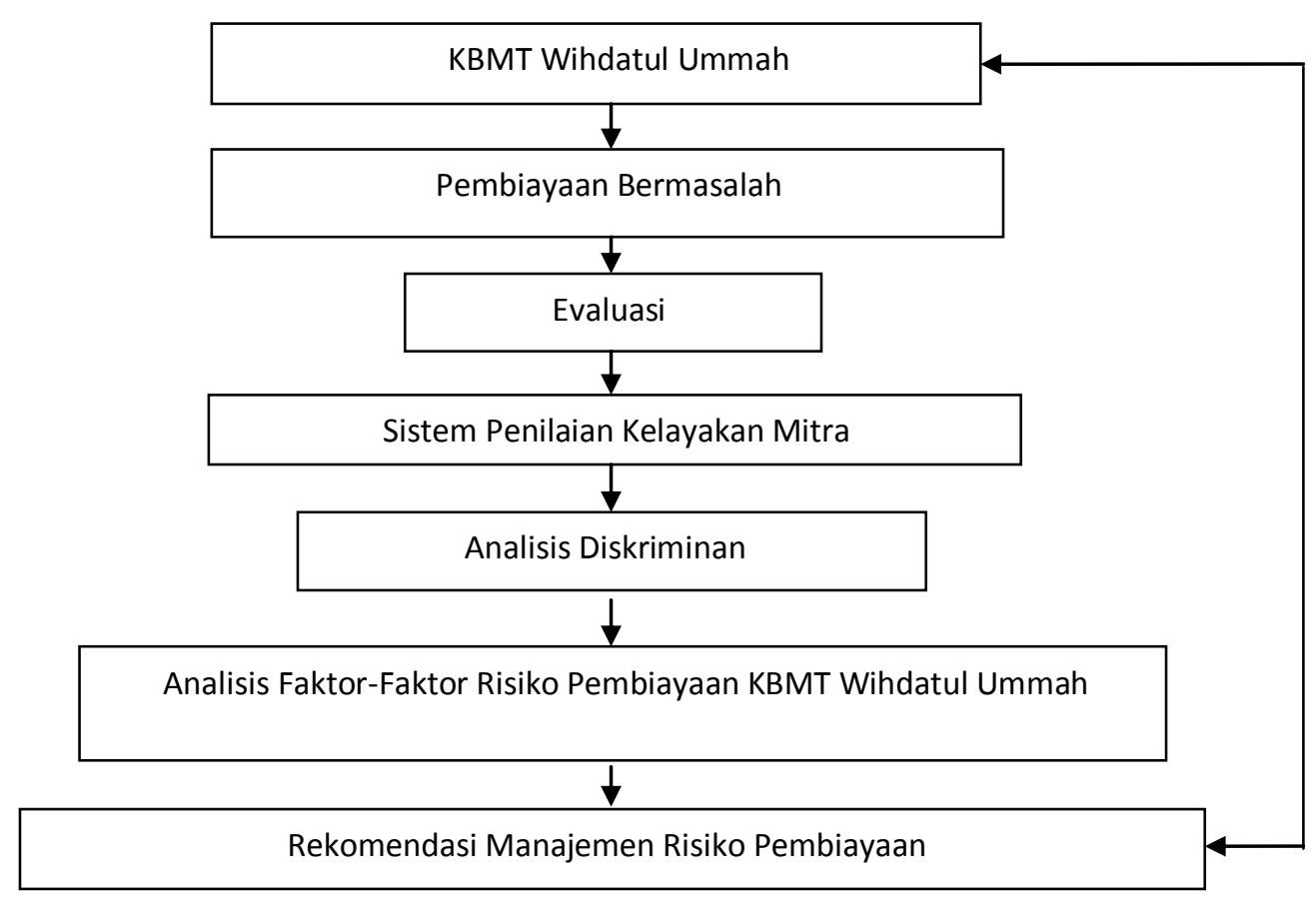

Gambar 1. Kerangka pemikiran penelitian

Data mitra yang digunakan adalah yang sedang mendapat pembiayaan di KBMT Wihdatul Ummah pada tahun 2011. Data mitra tersebut merupakan MAP yang sudah dianalisis oleh AO pada saat mitra mengajukan permohonan pembiayaan. Metode pengambilan sampel dilakukan dengan teknik probability sampling atau penarikan sampel secara acak dengan metode quota sampling. Tujuannya adalah untuk mengetahui bagaimana keterwakilan kelas dari jenis pembiayaan pada NPF yang dapat mewakili penyusunan indikator kelas kolektabilitas. Metode ini digunakan untuk memastikan bahwa berbagai subgrup dalam populasi telah terwakili dengan berbagai karakteristik sampel sampai batas tertentu seperti yang dikehendaki peneliti (Kuncoro 2003). Jumlah data debitur dalam penelitian ini didapat dari kalkulasi rumus Slovin sebagai berikut :

$$
\mathrm{n}=\frac{N}{1+N(e)^{2}}
$$

Keterangan :

$\mathrm{n}=$ Jumlah sampel

$N=$ Jumlah populasi

$e=$ Nilai kritis (eror) yang digunakan, yaitu $10 \%$

$\mathrm{n}=\frac{474}{1+474(0,1)^{2}}=82.578 \sim 83$ debitur 
Tabel 1. Quota sampling mitra pembiayaan KBMT Wihdatul Ummah

\begin{tabular}{lccc}
\hline \multicolumn{1}{c}{ Debitur } & Jumlah & $\%$ & Sampel \\
\hline Harian & 13 & 2.74 & 3 \\
Mingguan & 239 & 50.42 & 42 \\
Bulanan & 222 & 46.84 & 38 \\
\hline & $\mathbf{4 7 4}$ & $\mathbf{1 0 0}$ & $\mathbf{8 3}$ \\
\hline
\end{tabular}

Analisis data dalam penelitian ini menggunakan Analisis Diskriminan, dimana dengan analisis ini diharapkan dapat ditemukan indikator pembentuk kelas kolektabilitas. Kelas ini ditujukan untuk mengetahui parameter kelayakan pembiayaan KBMT dan memperbaiki memiliki sistem penilaian kelayakan mitra. Analisis diskriminan merupakan teknik menganalisis data, variabel tak bebas (disebut criterion) merupakan kategori (non-metrik, nominal, atau ordinal, bersifat kualitatif) sedangkan variabel bebas sebagai prediktor merupakan metrik (interval atau rasio, bersifat kuantitatif) (Supranto 2004). Variabel bebas (X) dari penelitian ini adalah variabel penjabaran dari 5C (character, capacity, collateral, condition, dan capital) dan pendekatan syarat BMT yang diambil dari MAP, sedangkan variabel tak bebasnya ( $\mathrm{Y}$ ) adalah tingkat risiko pembiayaan yang dikategorikan dengan kolektibilitas dan periode pembiayaan. Variabel-variabel bersifat tak bebas maka disebut Multiple Discriminant Analysis (Supranto 2004).

Menurut Simamora (2005), analisis diskriminan merupakan teknik yang akurat untuk memprediksi seseorang termasuk ke dalam kategori apa, dengan catatan datadata yang dilibatkan terjamin akurasinya. Model analisis diskriminan berkenaan dengan kombinasi linear yang bentuknya sebagai berikut :

$$
Z_{i}=b_{0}+b_{1} x_{11}+b_{2} x_{12}+b_{3} x_{13} \ldots+b_{j} x_{i j}+\ldots+b_{k} x_{i k}
$$

Dimana:

$Z_{i}=$ nilai (skor) diskriminan dari responden (objek) ke-i. $\mathrm{i}=1,2, \ldots, \mathrm{n}$. D merupakan variabel tak bebas.

$X_{i j}=$ variabel (atribut) ke-j dari responden ke-i.

$b_{j}=$ koefisien atau bobot diskriminan dari variabel atau atribut ke $\mathrm{j}$.

$X_{i j}=$ variabel bebas/prediktor ke-j dari responden ke-i, juga disebut atribut, seperti dijelaskan di atas.

\section{Hasil dan Pembahasan}

III.1. Sejarah Pendirian KBMT Wihdatul Ummah

Sejarah berdirinya KBMT Wihdatul Ummah tidak dapat dilepaskan dari Yayasan Pemberdayaan Dhuafa wal Mustadh'afin (PERAMU). Pada tanggal 17-21 Agustus 1994, diadakan pelatihan BMT oleh Yayasan PERAMU, persertanya adalah para kader PERAMU, utusan lembaga-lembaga Islam, Pesantren, dan lain-lain. Beberapa lulusan dari pelatihan tersebut akhirnya menjadi pengelola KBMT Wihdatul Ummah hingga saat ini. Setelah melalui beberapa persiapan, akhirnya pada tanggal 1 November 1994 KBMT Wihdatul Ummah secara efektif beroperasi. 


\section{III.2. Profil Yayasan PERAMU sebagai Pendamping KBMT Wihdatul Ummah}

PERAMU adalah organisasi yang bekerja atas dasar penelitian terhadap model lembaga keuangan mikro dan pengembangan terhadap prinsip-prinsip Islam. PERAMU menyediakan pinjaman kecil untuk masyarakat miskin dan merangsang mereka bahwa aman pada Lembaga Keuangan Mikro Syariah (LKMS) tersebut. PERAMU juga memiliki dana sosial yang mendukung proyek-proyek kecil masyarakat sangat miskin yang tidak diterima oleh bank biasa. Organisasi ini telah diselenggarakan sejak tahun 2005 hingga saat ini dan memiliki angota lebih dari 700 anggota tabungan dan kredit kelompok termiskin dan melayani 2000 pengusaha mikro. Aktifitas lembaga ini didedikasikan untuk tujuan redistribusi aset untuk orang-orang miskin melalui layanan pembiayaan mikro dan pendidikan dasar.

Yayasan PERAMU ini mendampingi beberapa lembaga ekonomi dan keuangan mikro. Lembaga-lembaga tersebut antara lain :

1. Lembaga Amil Zakat: Yayasan Baytul Maal Bogor, Kota Bogor

2. Lembaga microfinance/microbanking syariah:
a) PT BPRS Rif'atul Ummah (Bank BIRU), Kabupaten Bogor
b) KBMT Wihdatul Ummah, Kota Bogor
c) KBMT Khidmatul Ummah, Kabupaten Bogor
d) KBMT Tadbiirul Ummah, Kabupaten Bogor
e) KBMT Jamiatul Mubalighin, Kabupaten Sukabumi
f) KBMT Wasilah, Kota Bogor
g) Koperasi Baytul Ikhtiar, Kota/Kabupaten. Bogor

3. Working Group/Agency Takaful Mikro Indonesia (Takmin), Kota Bogor

\section{III.3. Prosedur Pemberian Pembiayaan di KBMT Wihdatul Ummah}

Mitra yang melakukan pengajuan ke KBMT Wihdatul Ummah terbagi dua, yaitu mitra anggota dan mitra biasa.

\section{Mitra Anggota}

Merupakan mitra BMT yang berasal dari mitra biasa yang telah mendapatkan pelatihan dari KBMT Wihdatul Ummah dan bersedia menjadi anggota KBMT Wihdatul Ummah. Proses yang harus dilewati oleh mitra ini adalah Pelatihan Calon Anggota (PCAG) dan Pelatihan Anggota (PAG).

\section{Mitra Biasa}

Merupakan mitra KBMT Wihdatul Ummah yang tidak menjadi anggota. Proses pengajuan pembiayaan pada KBMT Wihdatul Ummah meliputi proses sebagai berikut.

\section{a. Pengajuan Pembiayaan}

Mitra dapat melakukan pengajuan pembiayaan secara langsung datang ke BMT atau secara tidak langsung (hal ini berlaku untuk mitra lama). Untuk pengajuan pembiayaan dilakukan oleh Bagian Jasa Nasabah (Janas), dimana mitra pengaju akan diwawancara untuk pengisian Aplikasi Permohonan Pembiayaan (APP).

Apabila syarat BMT tidak dipenuhi, maka Bagian Janas dapat menyampaikan langsung penolakan pembiayaan kepada mitra pengaju. Apabila 
syarat dipenuhi dan setelah data lengkap dan mitra telah melampirkan salinan identitas diri beserta kartu keluarga, maka Bagian Janas mendistribusikan APP kepada Kepala Bagian Marketing untuk kemudian diproses selanjutnya. Kepala Bagian Marketing bertugas untuk menunjuk AO yang akan memproses pembiayaan yang diajukan tersebut.

b. Analisis Pengajuan Pembiayaan

AO yang memproses pembiayaan melakukan investigasi usulan pembiayaan. Langkah awal yang dilakukan adalah analisis data pada APP untuk bahan dalam melakukan survei usaha dan rumah atau biasa disebut dengan on the spot (OTS). Hal ini dilakukan untuk penyelidikan data yang ada pada APP apakah sesuai dengan kondisi di lapangan, untuk selanjutnya akan dibuat MAP. Apabila ternyata tidak terdapat kesesuaian antara data pada APP dengan hasil survey maka pembiayaan yang diajukan akan ditolak.

c. Persetujuan Komite Sirkuler BMT

Berkas MAP yang telah diproses oleh AO selanjutnya diajukan ke komite sirkuler. Berkas MAP didistribusikan kepada komite 1 dan 2 untuk selanjutnya ada Rencana Tindak Lanjut (RTL) apabila ada pertanyaan dari komite 1 dan 2 tentang hasil MAP, dan kemudian dikembalikan kepada $A O$ untuk dijawab. Jika pembiayaan telah mendapat persetujuan dari komite, maka AO melakukan negosiasi dengan mitra untuk memberitahu besarnya plafond, jumlah angsuran dan cara pembayaran. Apabila mitra menyetujui maka mitra menandatangani lembar persetujuan negosiasi untuk selanjutnya dibuat Surat Persetujuan Pembiayaan (SPP) dan semua berkas pembiayaan diserahkan kepada bagian Administrasi pembiayaan untuk selanjutnya dimintakan tanda tangan komite pembiayaan.

d. Pengikatan Pembiayaan dan Dropping Dana

Sebelum dilakukan pengikatan, semua dokumen hasil dan dokumen jaminan harus telah diterima. Setelah dilakukan pengikatan pembiayaan, proses dropping (realisasi) dana dapat dilakukan. Dropping dana dilakukan oleh Kepala Bagian Operasional, apabila yang bersangkutan tidak ada, maka dapat digantikan oleh Kepala Bagian Marketing danapabila yang bersangkutan juga tidak ada maka dilakukan oleh Administrasi Pembiayaan (ADMP), dan apabila tidak ada juga maka diganti oleh $A O$ tetapi bukan $A O$ yang memproses pembiayaannya. Pada waktu dropping dibacakan akadnya dan dilakukan verifikasi tanda tangan calon peminjam.

e. Monitoring

Kegiatan pemantauan dilakukan setiap hari Selasa dengan tujuan untuk melihat prestasi angsuran dari mitra dalam satu minggunya khususnya untuk mitra dengan sistem angsuran harian. Selain itu tujuan kegiatan ini adalah menentukan tindakan yang seharusnya dilakukan untuk menangani pembiayaan yang bermasalah dari mitra yang angsuran prestasinya kurang bagus. 
III.4. Faktor-Faktor yang Dijadikan Pertimbangan dalam Pemberian Pembiayaan di KBMT Wihdatul Ummah

Beberapa faktor yang dijadikan pertimbangan dalam pemberian pembiayaan di KBMT Wihdatul Ummah, antara lain :

1. Pendekatan syarat BMT
a. Lama usaha minimal 1 tahun
b. Plafond di bawah BMPK
c. Jangka waktu di bawah 18 bulan
d. Persetujuan istri/suami
e. Memenuhi BMTable

\section{Character}

Penilaian terhadap karakter atau kepribadian calon peminjam dilakukan dengan tujuan untuk memperkirakan kemungkinan bahwa peminjam dapat memenuhi kewajibannya. Hal lain yang perlu diperhatikan dalam character ada 14 variabel yaitu: pendapat pihak ke-3 terhadap mitra, tanggung jawab hutang kepada pihak lain dari mitra apakah ada, kolektibiltas pembiayaan sebelumnya (untuk mitra lama), ibadah langsung, tanggung jawab terhadap keluarga, hemat, pergaulan dengan tetangga, kesabaran, keterbukaan dengan BMT, keterbukaan pada keluarga, keuletan, kerendahatian serta penampilannya. Dari informasi tersebut dapat disimpulkan karakter dari mitra apakah baik, meragukan atau tidak baik.

3. Capacity

Penilaian tentang kemampuan mitra untuk mengelola bisnisnya apakah layak atau tidak layak untuk mendapatkan pembiayaan. Informasi yang dibutuhkan untuk penilaian kelayakan usaha ada 20 variabel yaitu tahun pendirian usaha, cara mempertahankan karyawan, lokasi usaha (bila tidak strategis bagaimana cara mengatasinya), sumber dan cara memperoleh barang, jenis dan cara mendapatkan konsumen, cara penjualan, faktor yang mempengaruhi harga, kualitas harga menurut $A O$, sarana penunjang usaha, pesaing, kemampuan mitra dalam mengelola usaha, kemampuan karyawan, modal awal, profit margin (PM) berdasarkan inventory turn over (ITO) bulanan, modal sekarang, PM dalam sebulan 3 kali mark up BMT apakah ada atau tidak, dan perkembangan usaha dibandingkan dengan usaha pada pengajuan sebelumnya apakah mengalami penambahan, tetap, atau penurunan. Pada akhirnya dapat diberikan kesimpulan apakah mitra usaha pengaju layak/tidak layak untuk mendapatkan pembiayaan.

4. Capital

Penilaian terhadap kemampuan modal yang dimiliki oleh calon peminjam, yang diukur dengan posisi pendapatan secara keseluruhan yang ditunjukkan oleh rasio finansialnya dan penekanan pada komposisi modalnya. Penilaian capital terkait dengan pendekatan saving power yaitu kemampuan mitra untuk melakukan angsuran dengan plafond yang sesuai.

\section{Collateral}

Terdapat 9 variabel dalam penilaian collateralatau jaminan yang dimiliki calon peminjamini yaitu : jenis jaminan, nama pemilik, persetujuan pemilik, tahun pembuatan, kondisi jaminan, nilai taksasi sekarang dan saat jatuh tempo, dan 
proyeksi plafond maksimal adalah $80 \%$ dari nilai taksasi saat jatuh tempo, sehingga diperoleh kesimpulan apakah jaminan memadai atau tidak.

6. Condition

Pihak BMT harus melihat kondisi keuangan dan ekonomi yang terjadi di masyarakat dan secara spesifik melihat adanya ketertarikan dengan jenis usaha yang dilakukan oleh calon peminjam.

Penilaian condition didasarkan pada titik kritis yang dihadapi oleh mitra baik dari sisi usaha, keluarga, maupun BMT sehingga terdapat 12 variabel.

a. Usaha

Pendekatan tentang faktor yang bepengaruh terhadap kinerja mitra dari segi konsumen, pemasok, karyawan, mental spekulasi, pesaing, kapabiliti mitra dalam mengelola usaha, kapabiliti karyawan, serta situasi eksternal yang dapat memperburuk kondisi usahanya.

b. Keluarga

Kesehatan, keharmonisan, pendidikan merupakan faktor yang dapat berpengaruh bagi usaha mitra dari segi keluarga untuk itu harus diketahui cara mengatasinya.

c. BMT

Menyangkut faktor internal yang digunakan oleh BMT tentang penilaian

terhadap mitra dan bagaimana cara mengatasinya.

Didapat 67 variabel yang dapat mewakili penilaian pendekatan $5 \mathrm{C}$ dan persyaratan BMT, sehingga dapat dilihat bahwa tugas AOpada lembaga keuangan mikro syariah sangatlah berat, dimana mereka harus terampil, teliti dan tepat dalam melakukan analisa kelayakan mitra. Apabila terjadi kekurangan informasi akan menimbulkan suatu risiko pembiayaan.

Variabel-variabel tersebut kemudian dijadikan variabel respon dalam analisis diskriminan untuk dilihat variabel-variabel apa saja yang paling mempengaruhi di dalam menentukan kolektibilitas dan periode pembiayaan yang tepat bagi mitranya.

III.5. Faktor-Faktor yang Mempengaruhi Risiko Pembiayaan KBMT Wihdatul Ummah pada Mitra

BMT telah memiliki sistem penilaian kelayakan mitra yang sudah mencakup penilaian pendekatan 5C dan persyaratan BMT. Sejauh ini, NPF KBMT Wihdatul Ummah cenderung menurun, akan tetapi hasil peramalan kedepan menunjukkan bahwa NPF KBMT Wihdatul Ummah akan mengalami peningkatan di atas standar $5 \%$ yang ditetapkan oleh Bank Indonesia, sehingga diperlukan sistem yang lebih prudent untuk mengantisipasi peramalan ini.

Usaha yang dapat dilakukan untuk mengantisipasi risiko NPF tersebut adalah melalui perbaikan pada internal KBMT Wihdatul Ummah sendiri, karena eksternal merupakan hal-hal yang tidak dapat dikendalikan tetapi pihak internal dapat mengantisipasinya dengan suatu sistem yang baik dan prudent. Untuk itu diperlukan evaluasi terhadap penilaian kelayakan mitra yang telah dilakukan KBMT Wihdatul Ummah. Dari evaluasi tersebut akan diketahui variabel-variabel apa saja yang memiliki pengaruh terdapat peningkatan risiko pembiayaan. Variabel-variabel tersebut diolah dengan analisis diskriminan menggunakan software MINITAB 14 serta bantuan dari 
gmacro untuk mengubah data nominal menjadi interval. Variabel dependen (respon) dalam penelitian ini berupa kategori-kategori yang merupakan variabel yang dapat mengukur tingkat risiko pembiayaan. Kategori-kategori tersebut adalah kolektibilitas dan periode pembiayaan. Hal ini disebabkan apabila KBMT Wihdatul Ummah dapat mengklasifikasikan mitranya dengan tepat berarti risiko pembiayaan dapat dikendalikan. Kolektibilitas adalah kualitas aktiva produktif yang dinilai dengan kriteria sesuai dengan ketentuan Surat Keputusan Direksi Bank Indonesia No.32/268/KEP/DIR tanggal 27 Februari 1998, yaitu lancar, kurang lancar, diragukan dan macet. Periode pembiayaan adalah satuan waktu yang ditetapkan oleh KBMT Wihdatul Ummah untuk pembayaran angsuran pembiayaan sesuai dengan pendapatannya yang terdiri dari harian, pekanan, dan bulanan. Sedangkan variabel independen (prediktor) merupakan penjabaran variabel-variabel dari pendekatan $5 \mathrm{C}$ dan persyaratan BMT.

Variabel-variabel dependen dan independen merupakan data sekunder yang peneliti ambil dari berkas MAP yang telah diisi AO. Dari 67 variabel hanya 19 variabel yang dapat digunakan,hal ini disebabkan adanya variabel yang tidak terisi oleh $A O$ sehingga software tidak dapat mengolah data tersebut. Syarat data agar dapat diolah adalah kelengkapan data.

Hasil pengolahan data menggunakan analisis diskriminan menunjukkan fungsi pembeda dari setiap kelompok kolektibilitas, dimana terdapat empat persamaan. Sedangkan dari setiap kelompok pembiayaan terdapat tiga persamaan.

1. Fungsi Diskriminan Berdasarkan Kolektibilitas

$$
\begin{aligned}
\mathrm{Z}_{1}= & -82.330+2.932 \mathrm{C} 11+7.869 \mathrm{C} 12+21.944 \mathrm{C} 13-1.357 \mathrm{C} 14+0.659 \mathrm{C} 15+ \\
& 0.873 \mathrm{C} 21+1.368 \mathrm{C} 23+5.961 \mathrm{C} 24-4.131 \mathrm{C} 25+8.122 \mathrm{C} 31-0.532 \mathrm{C} 32+ \\
& 3.615 \mathrm{C} 42+7.045 \mathrm{C} 51+19.247 \mathrm{C} 61+14.141 \mathrm{C} 63-28.039 \mathrm{C} 64 \ldots \ldots \ldots \ldots \ldots \ldots .(3) \\
\mathrm{Z}_{2}= & -83.915+1.618 \mathrm{C} 11+11.229 \mathrm{C} 12+17.284 \mathrm{C} 13+2.303 \mathrm{C} 14+0.491 \mathrm{C} 15+ \\
& 4.118 \mathrm{C} 21+14.586 \mathrm{C} 23-1.787 \mathrm{C} 24+1.922 \mathrm{C} 25+3.376 \mathrm{C} 31-0.855 \mathrm{C} 32+ \\
& 3.852 \mathrm{C} 42+5.033 \mathrm{C} 51+14.202 \mathrm{C} 61+11.642 \mathrm{C} 63-22.330 \mathrm{C} 64 \ldots \ldots \ldots \ldots \ldots \ldots(4) \\
\mathrm{Z}_{3}= & -64.202-0.533 \mathrm{C} 11-1.741 \mathrm{C} 12+29.546 \mathrm{C} 13-2.067 \mathrm{C} 14+0.511 \mathrm{C} 15+ \\
& 1.023 \mathrm{C} 21+2.201 \mathrm{C} 23+5.970 \mathrm{C} 24-3.511 \mathrm{C} 25+7.535 \mathrm{C} 31-1.961 \mathrm{C} 32+ \\
& 2.152 \mathrm{C} 42+4.355 \mathrm{C} 51+26.874 \mathrm{C} 61+12.950 \mathrm{C} 63-35.187 \mathrm{C} 64 \ldots \ldots \ldots \ldots \ldots \ldots . .(5) \\
\mathrm{Z}_{4}= & -59.672-1.523 \mathrm{C} 11+13.978 \mathrm{C} 12+18.906 \mathrm{C} 13-0.352 \mathrm{C} 14+0.796 \mathrm{C} 15+ \\
& 1.402 \mathrm{C} 21-3.433 \mathrm{C} 23+3.675 \mathrm{C} 24-2.440 \mathrm{C} 25+2.994 \mathrm{C} 31-1.155 \mathrm{C} 32+ \\
& 1.143 \mathrm{C} 42+2.826 \mathrm{C} 51+16.429 \mathrm{C} 61+8.186 \mathrm{C} 63-23.941 \mathrm{C} 64 \ldots \ldots \ldots \ldots \ldots \ldots . .(6)
\end{aligned}
$$

2. Fungsi Diskriminan Berdasarkan Periode Pembiayaan

$$
\begin{aligned}
Z_{H}= & -58.407-2.564 C 11+17.945 C 12-1.558 C 13+10.785 C 14+0.650 C 15- \\
& 0.223 C 21-0.724 C 23-0.050 C 24+3.254 C 25+2.832 C 31+3.320 C 32+ \\
& 1.784 C 42+0.896 C 51-8.754 C 61+0.412 C 63-6.556 C 64+16.216 C 65 \ldots .(7) \\
Z_{P}= & -65.072-2.051 C 11+16.586 C 12+10.220 C 13+8.085 C 14-0.901 C 15+ \\
& 1.251 C 21-4.011 C 23+1.273 C 24+3.689 C 25-0.715 C 31+3.310 C 32+ \\
& 0.610 C 42+0.208 C 51+8.210 C 61+3.937 C 63-9.629 C 64+3.461 C 65 \ldots \ldots .(8) \\
Z_{B}= & -77.646-2.310 C 11+16.115 C 12+5.420 C 13-11.674 C 14-0.657 C 15+ \\
& 0.257 C 21-4.690 C 23-0.442 C 24+6.261 C 25+3.120 C 31+4.392 C 32+ \\
& 0.900 C 42-0.583 C 51+4.943 C 61+2.747 C 63-4.044 C 64+4.535 C 65 \ldots . .(9)
\end{aligned}
$$


Dimana :

$\mathrm{Zk}_{1}$ : Skor Diskriminan berdasarkan kolektibilitas 1

$\mathrm{Zk}_{2}$ : Skor Diskriminan berdasarkan kolektibilitas 2

$\mathrm{Zk}_{3}$ : Skor Diskriminan berdasarkan kolektibilitas 3

$\mathrm{Zk}_{4}$ : Skor Diskriminan berdasarkan kolektibilitas 4

$Z_{\mathrm{H}_{H}}$ : Skor Diskriminan berdasarkan periode pembiayaan harian

$Z_{k_{p}}$ : Skor Diskriminan berdasarkan periode pembiayaan pekanan

$Z_{B}$ : Skor Diskriminan berdasarkan periode pembiayaan bulanan

a : Intersep

W : Bobot Diskriminan

C11 : Kolektibilitas PYD sebelumnya

C12 : Keterbukaan pada BMT

C13 : Keterbukaan pada keluarga

C14 : Kesimpulan karakter

C15 : Pembiayaan ke

$\mathrm{C} 21$ : Return of Investment (ROI)

C23 : Profit margin

C24 : Lokasi

C25 : Kesimpulan kelayakan usaha

C31 : Jenis jaminan

C32 : Kesimpulan nilai kolateral

C42 : rasio angsuran per saving power

C51 : titik kritis bisa diatasi

C61 : lama usaha/kerja

C63 : jangka waktu

C64 : persetujuan suami istri

C65 : memenuhi BMTable

Nilai harapan variabel respon diartikan sebagai kolektibilitas (kualitas pengembalian kredit) dan periode pembiayaan (jangka waktu pembayaran angsuran) yang merupakan ukuran dalam menilai tingkat risiko pembiayaan. Semua rating yang telah diubah menjadi nilai interval akan dikalikan dengan nilai bobot dari setiap variabelnya dan pada nilai maksimumnya berada disitulah mitra tersebut ditempatkan dan/atau cocok pada kolektibilitas dan periode pembiayaan yang mana.

Menurut Bhakti (2009), bobot dapat diartikan sebagai nilai dugaan keterkaitan setiap parameter (variabel penilaian) terhadap kolektibilitasnya, sehingga semakin besar bobot maka semakin besar keterkaitannya dengan kolektibilitas dan periode pembiayaan.

Pada Tabel 2 di bawah ini disajikan variabel-variabel dan diurutkan bobotnya, dimana bobot yang paling besar memiliki keterkaitan kuat dengan tingkat risiko pembiayaan. Semakin besar bobot maka semakin besar pengaruhnya terhadap tingkat risiko pembiayaan karena apabila mitra disalahtempatkan akan menimbulkan risiko yang tinggi.

Variabel-variabel yang paling menentukan mitra dikelompokkan ke dalam kolektibitas 1, 2, 3 dan 4 adalah persetujuan suami/istri dan keterbukaan pada 
keluarga. Persetujuan suami/istri merupakan variabel dari penilaian persyaratan BMT. BMT menerapkan variabel ini karena suami/istri harus mengetahui pembiayaan yang dilakukannya karena apabila mitra melakukan gagal bayar suami/istrinya dapat membantu membayar penunggakannya. Selain itu, sesuai dengan ajaran agama Islam yang merupakan landasan BMT, apabila ada uang keluar kedua belah pihak harus mengetahuinya, untuk itu apabila mitra mengajukan pembiayaan suami/istri wajib mengetahuinya. Keterbukaan pada keluarga merupakan variabel dari penilaian character. Keterbukaan ini diperhatikan oleh BMT karena apabila mitra mengalami gagal bayar, pihak keluarga tidak kaget pada saat aset miliknya diambil oleh pihak BMT atau apabila mitra mengalami keterlambatan angsuran pihak keluarga dapat membantu menanggung angsurannya.

Tabel 2. Faktor yang paling mempengaruhi dalam penempatan kolektibilitas mitra

\begin{tabular}{cccccccc}
\hline \multicolumn{2}{c}{ Koll.1 } & \multicolumn{2}{c}{ Koll.2 } & \multicolumn{2}{c}{ Koll.3 } & \multicolumn{2}{c}{ Koll.4 } \\
\hline Variabel & Koef. & Variabel & Koef. & Variabel & Koef. & Variabel & Koef. \\
\hline C64 & $\mathbf{2 8 . 0 3 9}$ & C64 & $\mathbf{2 2 . 3 3 0}$ & C64 & $\mathbf{3 5 . 1 8 7}$ & C64 & $\mathbf{2 3 . 9 4 1}$ \\
C13 & $\mathbf{2 1 . 9 4 4}$ & C13 & $\mathbf{1 7 . 2 8 4}$ & C13 & $\mathbf{2 9 . 5 4 6}$ & C13 & $\mathbf{1 8 . 9 0 6}$ \\
C61 & 19.247 & C23 & 14.586 & C61 & 26.874 & C61 & 16.429 \\
C63 & 14.141 & C61 & 14.202 & C63 & 12.950 & C12 & 13.978 \\
C31 & 8.122 & C63 & 11.642 & C31 & 7.535 & C63 & 8.186 \\
C12 & 7.896 & C12 & 11.229 & C24 & 5.970 & C24 & 3.675 \\
C51 & 7.045 & C51 & 5.033 & C51 & 4.355 & C23 & 3.433 \\
C24 & 5.961 & C21 & 4.118 & C25 & 3.511 & C31 & 2.994 \\
C25 & 4.131 & C42 & 3.852 & C23 & 2.201 & C51 & 2.826 \\
C42 & 3.615 & C31 & 3.376 & C42 & 2.152 & C25 & 2.440 \\
C11 & 2.932 & C14 & 2.303 & C14 & 2.067 & C11 & 1.532 \\
C23 & 1.368 & C25 & 1.922 & C32 & 1.961 & C21 & 1.402 \\
C14 & 1.357 & C24 & 1.787 & C12 & 1.741 & C32 & 1.155 \\
C21 & 0.873 & C11 & 1.618 & C21 & 1.023 & C42 & 1.143 \\
C15 & 0.659 & C32 & 0.855 & C11 & 0.533 & C15 & 0.796 \\
C32 & $\mathbf{0 . 5 3 2}$ & C15 & $\mathbf{0 . 4 9 1}$ & C15 & $\mathbf{0 . 5 1 1}$ & C14 & $\mathbf{0 . 3 5 2}$ \\
\hline
\end{tabular}

Sumber: Data diolah (2012)

Variabel yang memiliki pengaruh paling kecil pada kolektibilitas 1 adalah kesimpulan nilai kolateral. Hal ini membuktikan bahwa BMT tidak mementingkan variabel jenis jaminan seperti perbankan. BMT lebih memikirkan dampak positif yang diperoleh mitranya dengan bantuan pembiayaan yang diberikan, dan menilai dengan sangat prudent karakter mitra melalui orang-orang terdekatnya agar terhindar dari risiko gagal bayar. Variabel yang memiliki pengaruh paling kecil pada kolektibilitas 2 dan 3 adalah jumlah pembiayaan. Mitra telah melakukan pembiayaan yang ke berapa bukan menjadi faktor yang terlalu mempengaruhi risiko pembiayaan, karena keadaan ekonomi dan finansial seseorang dari waktu ke waktu berbeda, sehingga bukanlah menjadi ukuran yang baik dalam menentukan risiko pembiayaan. Variabel yang memiliki pengaruh paling kecil pada kolektibilitas 4 adalah kesimpulan karakter. Kesimpulan karakter menjadi faktor yang tidak berpengaruh untuk kelompok macet ini karena untuk menilai mitra dalam posisi macet bukan lagi dilihat karakternya secara keseluruhan, melainkan karakternya mengenai tanggung jawabnya terhadap amanah yang tidak bisa dilihat secara general di kesimpulan karakter. Variabel-variabel yang 
paling mempengaruhi mitra ditempatkan pada pembiayaan mana dapat dilihat ada Tabel 3.

Tabel 3. Faktor yang paling mempengaruhi dalam penempatan periode pembiayaan mitra

\begin{tabular}{cccccc}
\hline \multicolumn{2}{c}{ Harian } & \multicolumn{2}{c}{ Pekanan } & \multicolumn{2}{c}{ Bulanan } \\
\hline Variabel & Koef. & Variabel & Koef. & Variabel & Koef. \\
\hline C12 & $\mathbf{1 7 . 9 4 5}$ & C12 & $\mathbf{1 6 . 5 8 6}$ & C12 & $\mathbf{1 6 . 1 1 5}$ \\
C65 & $\mathbf{1 6 . 2 1 6}$ & C13 & $\mathbf{1 0 . 2 2 0}$ & C14 & $\mathbf{1 1 . 6 7 5}$ \\
C14 & 10.785 & C64 & 9.629 & C25 & 6.261 \\
C61 & 8.754 & C61 & 8.210 & C13 & 5.420 \\
C64 & 6.556 & C14 & 8.085 & C61 & 4.943 \\
C32 & 3.320 & C23 & 4.011 & C23 & 4.690 \\
C25 & 3.254 & C63 & 3.937 & C65 & 4.535 \\
C31 & 2.832 & C25 & 3.689 & C32 & 4.392 \\
C11 & 2.564 & C65 & 3.461 & C64 & 4.044 \\
C42 & 1.784 & C32 & 3.310 & C31 & 3.120 \\
C13 & 1.558 & C11 & 2.051 & C63 & 2.747 \\
C51 & 0.896 & C24 & 1.273 & C11 & 2.310 \\
C23 & 0.724 & C21 & 1.251 & C42 & 0.900 \\
C15 & 0.650 & C15 & 0.901 & C15 & 0.657 \\
C63 & 0.412 & C31 & 0.715 & C51 & 0.583 \\
C21 & 0.223 & C42 & 0.610 & C24 & 0.442 \\
C24 & $\mathbf{0 . 0 5 0}$ & C51 & $\mathbf{0 . 2 0 8}$ & C21 & $\mathbf{0 . 2 5 7}$ \\
\hline
\end{tabular}

Sumber: Data diolah (2012)

Variabel-variabel yang paling menentukan mitra dikelompokkan ke dalamperiode pembiayaan harian, mingguan, dan bulanan adalah keterbukaan pada BMT. Keterbukaan pada BMT ini merupakan penilaian character. Periode pembiayaan biasanya disesuaikan dengan penghasilan yang didapatkan oleh mitra apakah per hari, per minggu atau per bulan, untuk itu dibutuhkan keterbukaan mitra di dalam mengkomunikasikan pendapatannya agar BMT bisa menempatkan periode pembiayaan yang sesuai. Selain itu, variabel yang menentukan lainnya untuk periode pembiayaan harian adalah memenuhi BMTable. Memenuhi BMTable merupakan kesimpulan dari semua variabel persyaratan BMT. Biasanya, pendapatan per hari memiliki jumlah yang tidak tentu sehingga persyaratan BMT harus dipenuhi semuanya untuk menghindari gagal bayar. Variabel yang berpengaruh lainnya untuk periode pekanan adalah keterbukaan pada keluarga. Seperti yang dijelaskan sebelumnya, keterbukaan pada keluarga ini sebagai bentuk antisipasi apabila mitra melakukan penunggakan. Mitra periode mingguan ini memiliki proporsi mitra pada kolektibilitas macet lebih banyak dibandingkan harian dan bulanan sehingga variabel keterbukaan pada kelurga merupakan hal yang paling diperhatikan juga. Variabel yang berpengaruh lainnya untuk periode bulanan adalah kesimpulan karakter. Kesimpulan karakter merupakan keseluruhan karakter mitra yang dinilai oleh $A O$ apakah baik atau tidak. Periode bulanan ini memiliki interaksi yang jarang dengan kolektor dan AO sehingga diperlukan sikap prudent terhadap karakter mitra untuk mengantisipasi mitra kabur.

Variabel yang memiliki pengaruh paling kecil untuk mengelompokkan mitra pada periode pembiayaan adalah lokasi usaha, mengatasi titik kritis dan ROI. Hal ini disebabkan periode pembiayaan hanya melihat dari segi pendapatan mitra dan 
keterbukaannya pada BMT sehingga sisi usaha mitra menjadi hal yang kurang mempengaruhinya terhadap risiko pembiayaan melalui kategori periode pembiayaan.

Dapat disimpulkan dari kedua kategori diskriminan variabel-variabel yang paling diperhatikan dalam menentukan kolektibilitas dan periode pembiayaan mitra adalah faktor character dan faktor persyaratan BMT. Hasil penelitian melengkapi hasil penelitian Hayati (2006), sehingga memperjelas sistem penilaian pembiayaan yang baik. Namun perlu diingat bahwa hasil ini tidak dapat digeneralisir pada BMT lain karena merupakan faktor yang khusus pada KBMT.

\section{III.6. Implikasi Manajerial}

Implikasi manajerial dari hasil penelitian ini dapat digunakan untuk pengendalian pembiayaan mitra pada KBMT Wihdatul Ummah, sebagai dasar kegiatan manajemen risiko yang harus dilaksanakan dan bagaimana proses perencanaan selanjutnya dalam memberikan pembiayaan kepada mitra baik dari segi sistem pembiayaan mitra yang ada atau pengembangan sumber daya manusia. Tabel 4 di bawah ini akan menunjukkan perencanaan, implementasi, dan pengendalian dari kajian yang dapat dilakukan.

Tabel 4. Implikasi manajerial

\begin{tabular}{lll}
\hline \multicolumn{1}{c}{ Perencanaan } & \multicolumn{1}{c}{ Implementasi } & \multicolumn{1}{c}{ Pengendalian } \\
\hline $\begin{array}{l}\text { Mempersiapkan manajemen risiko } \\
\text { pembiayaan dengan penekanan } \\
\text { pada pendekatan character dan } \\
\text { persyaratan BMT. }\end{array}$ & $\begin{array}{l}\text { Memperkuat pemahaman tenaga } \\
\text { marketing dengan memanfaatkan } \\
\text { sistem penilaian kelayakan } \\
\text { pembiayaan mitra, baik berdasarkan } \\
\text { periode pembiayaan atau } \\
\text { berdasarkan kolektibilitasnya. }\end{array}$ & $\begin{array}{l}\text { a. } \\
\text { tersebut, maka diperlukan } \\
\text { evaluasi terhadap pelaksanaan } \\
\text { penerapan manajermen risiko, } \\
\end{array}$ \\
& & $\begin{array}{l}\text { agar dapat dideteksi secara } \\
\text { dini risiko pembiayaan yang }\end{array}$ \\
& & timbul sebagai akibat dari \\
& & kesalahan atau kelemahan \\
& & sistem. \\
& & b. Hal ini ditujukan untuk \\
& membangun perbaikan sistem \\
& & secara terus menerus dan \\
& memperkuat sistem secara \\
\end{tabular}

\section{Kesimpulan}

Faktor-faktor yang paling mempengaruhi dari sistem penilaian kelayakan mitra di dalam menentukan kolektibilitas berdasarkan fungsi diskriminan adalah faktor pendekatan character dan faktor persyaratan BMT, dengan variabel persetujuan suami/istri dan keterbukaan pada keluarga. Faktor-faktor yang paling mempengaruhi dari sistem penilaian kelayakan mitra di dalam menentukan periode pembiayaan mitra berdasarkan fungsi diskriminan adalah faktor pendekatan character dan faktor persyaratan BMT, dengan variabel keterbukaan pada BMT, memenuhi BMTabel, keterbukaan pada keluarga, dan kesimpulan karakter. Hasil ini tidak dapat digeneralisir karena merupakan faktor yang khusus pada KBMT. 


\section{Daftar Pustaka}

Abdullah. 2004. Berbagai Masalah yang dihadapi oleh Usaha Simpan Pinjam Koperasi sebagai Lembaga Keuangan Mikro [internet]. [diunduh 2012 April 1]. Tersedia pada: www.smecda.com/deputi7/file_Infokop/EDISI\%2024/ismeth.htm.

Bhakti. 2009. Analisis Diskriminan dalam Klasifikasi Pola Pengembalian Kredit Sektor Pertanian (Studi Kasus PT Bank XYZ) [skripsi]. Bogor (ID): Institut Pertanian Bogor.

Hayati. 2006. Identifikasi Risiko Operasional Bidang Pembiayaan pada Lembaga Keuangan Mikro (Studi Kasus KBMT Wihdatul Ummah) [skripsi]. Bogor (ID): Institut Pertanian Bogor.

Kasidi M. 2010. Manajemen Risiko. Jakarta (ID): Ghalia Indonesia.

Kuncoro M. 2003. Metode Riset untuk Bisnis dan Ekonomi: Bagaimana Meneliti dan Menulis Tesis. Jakarta (ID): Erlangga.

Muhammad. 2005. Manajemen Pembiayaan Bank Syari'ah. Yogyakarta (ID): Akademi Manajemen Perusahaan YKPN.

Simamora B. 2005. Analisis Multivariat Pemasaran. Jakarta (ID): PT Gramedia Pustaka Utama.

Sofyan I. 2005. Manajemen Risiko. Yogyakarta (ID): Graha Ilmu.

Sudarsono H. 2008. Bank dan Lembaga Keuangan Syariah. Yogyakarta (ID): Ekonisia.

Supranto J. 2004. Analisis Multivariat: Arti dan Interpretasi. Jakarta (ID): PT Rineka Cipta. 